\title{
Design and Implementation of Bekantan Educational Game (BEG) as a Banjar Language Learning Media
}

\author{
https://doi.org/10.3991/ijim.v13i03.9257 \\ Aulia Akhrian Syahidi ${ }^{\bowtie}$, Ahmad Afif Supianto, Herman Tolle \\ Brawijaya University, Malang, East Java, Indonesia \\ aakhriansyahidi@student.ub.ac.id
}

\begin{abstract}
The lack of recognition of the current Banjar language is one of the causes of knowledge and the introduction of children about the reduced Banjar language. In an attempt to recognize, introduce, and improve the reknowledge of the Banjar language is to recommend the design and implementation of an educational game application called Bekantan Educational Game (BEG) containing material content and quizzes. Before this game application is used, it must be tested first. Test method used is black box testing, to test the functionality of game applications. Other tests are also conducted to obtain information about the material access frequency and reset quizzes by players. The result of black box testing is all the functionality in the BEG application in accordance with what is expected. The result of the frequency testing accessing the menu on BEG of Material Section is Wadai Banjar 2 Menu with 59 times, and the frequency reset on BEG of Quiz Section is a type of Drag and Drop quiz with 21 times and generate feedback from quiz in the form of final value with average $89.17 \%$.
\end{abstract}

Keywords-Educational game, black box testing, game application, user interface, learning media

\section{Introduction}

South Kalimantan is one of the provinces in Indonesia that has a variety of art and culture. Today, many arts or cultures are slowly being forgotten. The interest of the younger generation to understand Banjar art and culture was reduced. The lack of recognition of Banjar art and culture since the early days has also been one of the causes of the lack of interest of children to learn and try Banjar art and culture, one of which is introducing and giving knowledge about Banjar language as one of Banjar art and culture that should be maintained [1]. Through the Culture and Tourism Office of Banjarmasin City, Banjarmasin Mayor directly instructed to preserve the art and culture of Banjar in particular continuously preserving the use of Banjar language in the daily life of Banjar people. Banjar language is very necessary to be preserved and reintroduced so as not to be eroded by the times. The introduction of the Banjar language is not enough only orally or in writing, it needs a solution to face the current era 
by recommending the use of learning media technology to increase the interest and interest of the children to be more familiar with and learn Banjar language.

Educational game is a game application technology, which through the game, there are materials or information that is educational. Such material or information may be directly expressed in multimedia applications and may also be implied through the plot of the game in the application itself [2].

Quite a lot of research has discussed about educational games such as research by [5], [7], [10], [11], [12], [13], [15], and [16] which each deals with design, implementation, analysis, and identification of educational games, which distinguishes most of the educational game tools used and different materials.

Research that raised and discussed about educational game with element of art and culture of region that is research conducted by [14] which discuss about traditional art education game on story puppet by using digital story.

A highly relevant study is a study conducted by [4], which together promotes Banjar art and culture, which displays a character by the name of Si Palui who adventures to find the knowledge then at the end of the game will be given a quiz. However, for general content material covered from Banjar art and cultural subjects, not specified. Then to develop the game Si Palui this researcher [4] also uses Flash. One of the most widely used and easy-to-use programs for creating and developing learning media that contain animation, graphics, text and sound is the Flash application. With Flash Programming, we can create a variety of multimedia applications ranging from presentation, animation, learning media and even the making of games, especially educational games. In flash, use action script as its programming language [3].

What distinguishes the research [4] with the current recommended research is on the storyline of the game, game type, game background, and more specific material that is about the introduction of the Banjar language.

Based on some backgrounds above, then do the design and implementation of educational game application called "Bekantan Educational Game (BEG)". Where with this educational game can make the teaching-learning process more interesting and easy in understanding and expected in the future with this application, knowledge of Banjar language can increase. This application can also make it easier for teachers to explain the material of Banjar language. In addition, applications built later can be used as a tool or media for the introduction of art and culture of Banjar to students in schools and general public, especially in preserving the language of Banjar as a colloquial.

\section{Educational Game}

According to Thomas Grill defining about the notion of games is a game is structured playing, usually undertaken for enjoyment and sometimes used as an educational tool. Games are distinct from work, which is usually carried out for remuneration. Games generally involve mental and/or physical stimulation [6]. 
Educational game according to Andang Ismail in his book titled education games, which is a very fun activity and can be an educational way or educational tool. The functions of the educational game are as follows:

- Providing knowledge to the child through the process of learning to play while learning.

- Stimulate the development of thinking power, and creativity and language in order to foster attitudes, mental, and good morals.

- Create an exciting playing environment; provide a sense of security, and fun.

- Improving the quality of learning [8].

Educational game is a creative game that can help children in providing knowledge, education and how to solve problems. An educational game is also able to apply the logic of thinking for player and train the learning system on a positive effect on the brain of Pre Fortal Cortex. Educational games are widely used as a learning medium capable of supporting the wheel of education in the community with the concept of learning and playing along with an interesting visual for the players [16].

\section{Banjar Language}

The Banjar language is an Austronesian language of the Melayik language group spoken by the Banjar tribe in South Kalimantan, Indonesia, as the mother tongue. Some linguists argue the Banjar Language includes the Malay Local Borneo East group. The Banjar language is included in the list of dominant languages in Indonesia. In his native land in South Kalimantan, the Banjar language is an oral literary language divided into two major dialects namely Banjar Kuala and Banjar Hulu. Before known as the national language of Indonesia, in ancient times when making speeches, writing or composing Banjar people using Banjar Malay language using Arabic script. The writings or letters used are mostly Arabic letters or Arabic writing with Malay language (Banjar version). All ancient hand-written manuscripts such as poetry, Syair Siti Zubaidah, Tajul Muluk poetry, Karuang Bird poetry, and even Hikayat Banjar and Tutur Temple use Arabic Malay (Banjar). The use of Banjar language in daily conversation and interaction in South Kalimantan and its surroundings is more dominant than Indonesian language. Various tribes in South Kalimantan and surrounding areas try to master the language of Banjar, so we can also encounter Banjar language spoken with Javanese or Madura accents that still feel thick as we encounter in the city of Banjarmasin.

The Banjar language is still used in some Banjar settlements in Malaysia such as Kampung (Desa) Parit Abas, Mukim (Kecamatan) Kuala Kurau, Kerian District, Darul Ridzuan State. The language of Banjar is much influenced by Malay, Javanese, and Dayak languages. The similarity of lexical Banjar language to other languages is $73 \%$ with Indonesian, 66\% with Tamuan language (Malayic Dayak), 45\% with Bakumpai language, $35 \%$ with Ngaju language. Results of research Wurm and Willson (1975), kinship relationship between Malay and Banjar language reaches $85 \%$. The kinship with Maanyan language is about $32 \%$ and with $39 \%$ Ngaju 
language, based on Zaini HD research. The Banjar language is related to the language used by the Kedayan tribe (a dialect in Brunei) that is separated for 400 years and the Banjar language is often also called Banjar Malay. In its development, Banjar language is suspected to have contamination from Indonesian and foreign language intervention. The Banjar languages are in a fairly safe category of extinction because they are still used as a colloquial language by the Banjar community as well as by outsiders. Despite the decline in Banjar language playings, the rate of decline is not very subtle. Currently, Banjar Language has begun to be taught in schools in South Kalimantan as local content. The Banjar language also has a number of proverbs [9].

\section{$4 \quad$ Research Methodology}

There are several steps in doing this research as shown in Fig. 1. This is a general explanation of the steps in the research methodology.

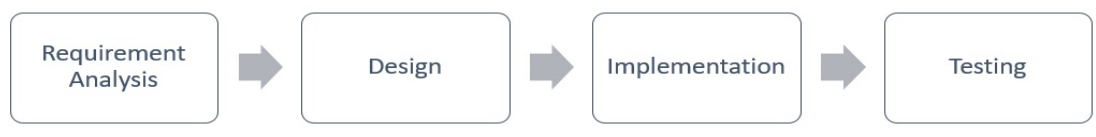

Fig. 1. Research Methodology

\subsection{Requirement analysis}

Initial stage is requirement analysis that is complete requirement gathering then analyzed and specified requirement which must be fulfilled by application to be built. This step analysis needs to be done in full to be able to produce a complete design. Collection of materials and reviews of art and culture textbooks to discuss Banjar language materials. In this discussion discussed about some function and purpose of making application so that later target more appropriate and as expected.

\subsection{Design}

After the results of the analysis of the data obtained into an idea in the development of applications, the problems that may occur, what needs are required in the development of this application. After all the needs are analyzed, the next step is to design the system and software, which is to design the system to be built such as the storyboard and wireframe design.

\subsection{Implementation}

Implementation is the stage of applying the results of design, interface design, and system into an application. The software used in making this application is Macromedia Flash 8, Photoscape, and Corel Draw X7. 


\subsection{Testing}

The testing phase is done after the application is completed. This test is done using black box testing method. This test is performed to test the functionality of game apps as well as testing to get information about the frequency of accessing the menu on the BEG of the material part and frequency of reset the quiz on the BEG quiz section of the game app by selecting the player's sample to use this BEG.

\section{$5 \quad$ Results and Discussion}

\subsection{Requirement analysis}

This application is in the form of an educational game containing material content and quiz, players can learn by themselves visually about writing Banjar language at the same time see picture which is explained in Banjar language. The material presented is a Brief History of Banjar Language, Daily Language, Family, Fruit, Animals, Wadai Banjar 1 (Banjar Food 1), and Wadai Banjar 2 (Banjar Food 2). After the player finishes the material, then will be directed to work on the quiz in which the quiz system is random, consisting of 6 types of quiz: Drag and Drop, Fill in the Blank, Hot Objects, Hot Spots, Multiple Choice, and True or False. In this BEG application, a few menus are described and presented in Table 1 and Table 2.

Table 1. Features on the BEG menu of the material section

\begin{tabular}{|c|l|l|}
\hline Id & \multicolumn{1}{|c|}{ Menu Features } & \multicolumn{1}{|c|}{ Description } \\
\hline MU & Utama & $\begin{array}{l}\text { Initial view of the BEG application of the Content section that } \\
\text { contains some of the options menu. }\end{array}$ \\
\hline M1 & Petunjuk Aplikasi & $\begin{array}{l}\text { Displays a page that contains the rules or guidelines for using } \\
\text { BEG applications. }\end{array}$ \\
\hline M2 & Sejarah Singkat Bahasa Banjar & Displays a page containing a brief history of Banjar language. \\
\hline M3 & Bahasa Keseharian & $\begin{array}{l}\text { Displays a page containing daily language materials that are often } \\
\text { used daily by Banjar people who have been sorted from the letter } \\
\text { A-Z. }\end{array}$ \\
\hline M4 & Keluarga & $\begin{array}{l}\text { Displays pages that contain about family introduction materials, } \\
\text { such as father, mother, sister, and so forth in Banjar. }\end{array}$ \\
\hline M5 & Buah & $\begin{array}{l}\text { Displays a page containing the image and the name of the fruit in } \\
\text { Banjar. }\end{array}$ \\
\hline M6 & Binatang & $\begin{array}{l}\text { Displays a page containing the image and the name of the animal } \\
\text { in Banjar. }\end{array}$ \\
\hline M7 & Wadai Banjar 1 & $\begin{array}{l}\text { Displays a page containing the pictures and writing of Banjar's } \\
\text { unique food names in Banjar. }\end{array}$ \\
\hline M8 & Wadai Banjar 2 & $\begin{array}{l}\text { Displays a page containing the pictures and writing of Banjar's } \\
\text { unique food names in Banjar (Continuation). }\end{array}$ \\
\hline
\end{tabular}


Table 2. Features on the BEG menu of the quiz section

\begin{tabular}{|c|c|c|}
\hline Id & Quiz Features & Description \\
\hline MUK & Menu Utama & $\begin{array}{l}\text { Initial view of the Quiz section BEG app containing some selection menus. On } \\
\text { this page provided the next button that serves to start working on the quiz. }\end{array}$ \\
\hline $\mathrm{K} 1$ & Drag and Drop & $\begin{array}{l}\text { Displaying the quiz type by pairing or matching the image, this quiz system is } \\
\text { the picture presented totaling } 4 \text { pieces on the left side and on the right side is } \\
\text { where to put a picture of } 4 \text { pieces corresponding to the naming. Then, if the } \\
\text { player wants to repeat the answer provided by the reset button, if the player is } \\
\text { sure with the answer then click the check button answer, and raises the message } \\
\text { in the form of: "Is your answer right or wrong?" This quiz system should not } \\
\text { return to the previous problem and the appearance of quizzes between random } \\
\text { players. }\end{array}$ \\
\hline $\mathrm{K} 2$ & Hot Objects & $\begin{array}{l}\text { Displays the quiz types of the image guessed by the question asked. This quiz } \\
\text { system is a picture presented totaling } 6 \text { pieces, the player will select the image } \\
\text { that has been provided and adjust it. Then, if the player wants to repeat the } \\
\text { answer provided by the reset button, if the player is sure with the answer then } \\
\text { click the check button answer, and raises the message in the form of: "Is your } \\
\text { answer right or wrong?" This quiz system should not return to the previous } \\
\text { problem and the appearance of quizzes between random players. }\end{array}$ \\
\hline $\mathrm{K} 3$ & Fill in the Blank & $\begin{array}{l}\text { Displaying the quiz type field, the player will fill in the answer on the text box } \\
\text { that has been provided, and the system does not set case sensitive. So, the player } \\
\text { can enter the answer whether it is uppercase or lowercase. If the player is confi- } \\
\text { dent with the answer then click the check button answer, and raises the message } \\
\text { in the form of: "Is your answer right or wrong?" This quiz system should not } \\
\text { return to the previous problem and the appearance of quizzes between random } \\
\text { players. }\end{array}$ \\
\hline K4 & Hot Spot & $\begin{array}{l}\text { Displays the quiz types of the image guessed by the question asked. This quiz } \\
\text { system is a picture presented totaling } 6 \text { pieces; the player will select the image } \\
\text { that has been provided and adjust it. Then, if the player wants to repeat the } \\
\text { answer provided by the reset button, if the player is sure with the answer then } \\
\text { click the check button answer, and raises the message in the form of: "Is your } \\
\text { answer right or wrong?" This quiz system should not return to the previous } \\
\text { problem and the appearance of quizzes between random players. }\end{array}$ \\
\hline K5 & True or False & $\begin{array}{l}\text { Displaying a quiz type chooses whether the answer is true or false and only one } \\
\text { correct answer, the player will choose between the true or false options that have } \\
\text { been provided according to the instructions of the statement by clicking the } \\
\text { option on the answer. If the player is confident with the answer then click the } \\
\text { check button answer, and raises the message in the form of: "Is your answer } \\
\text { right or wrong?" This quiz system should not return to the previous problem and } \\
\text { the appearance of quizzes between random players. }\end{array}$ \\
\hline K6 & Multiple Choice & $\begin{array}{l}\text { Displaying a multiple-choice quiz type, the player will select some of the correct } \\
\text { answers that have been provided according to the instructions of the question by } \\
\text { clicking on the options in the answer. If the player is confident with the answer } \\
\text { then click the check button answer, and raises the message in the form of: "Is } \\
\text { your answer right or wrong?" This quiz system should not return to the previous } \\
\text { problem and the appearance of quizzes between random players. }\end{array}$ \\
\hline QR & Quiz & $\begin{array}{l}\text { Displays the results of a quiz work consisting of total correct, total incorrect, and } \\
\text { total score. }\end{array}$ \\
\hline
\end{tabular}

\subsection{Design with storyboard and wireframe}

Storyboard game explains the storyline or plot of the game on a BEG app. One example of storyboard from BEG is shown in Fig. 2. 


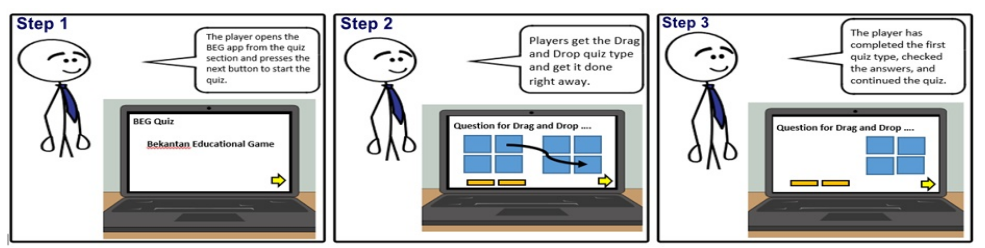

Fig. 2. Storyboard game for quiz section

The game's wireframe here visualizes the User Interface (UI) design of the games in this BEG app. This BEG application is divided into 2 main scenes namely Scene Material and Scene Quiz. The designed wireframe is visualized using a desktop and web-based and mobile-based. Examples of BEG wireframes from the material section are presented in Fig. 3 and Fig 4. Examples of BEG wireframes from the quiz section are presented in Fig. 5 and Fig. 6.

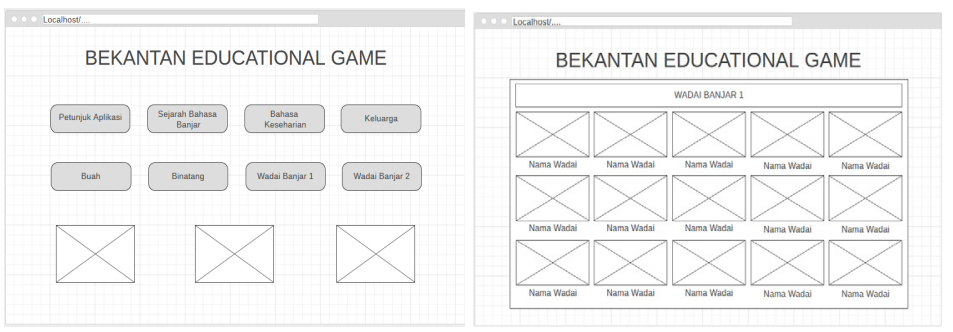

Fig. 3. BEG wireframe from the material section using desktop and web-based
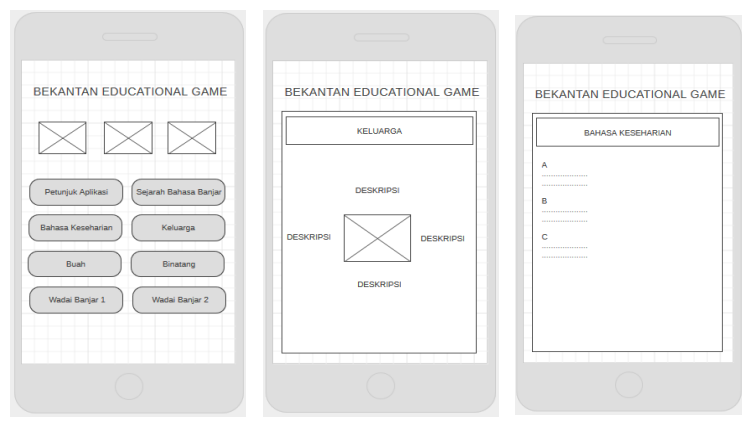

Fig. 4. BEG wireframe from the material section using mobile-based

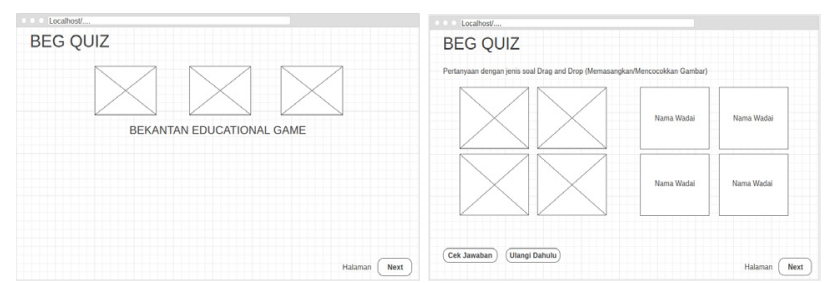

Fig. 5. BEG wireframe from the quiz section using desktop and web-based 

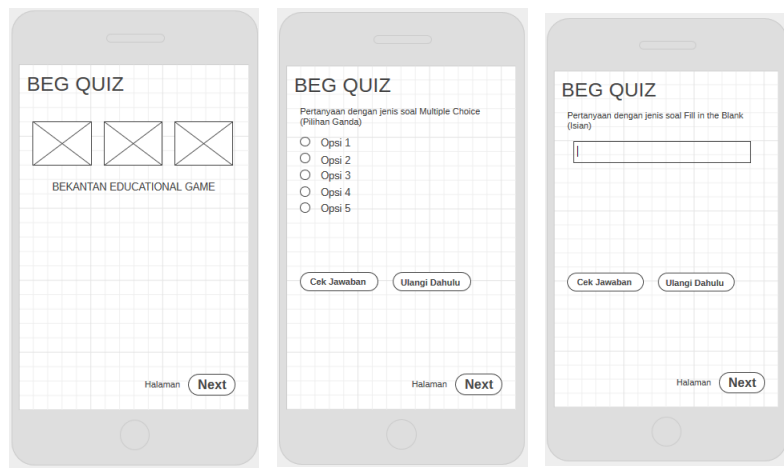

Fig. 6. BEG wireframe from the quiz section using mobile-based

\subsection{Implementation}

After the process of analysis and data collection, as well as system design, then made this BEG application using flash programming language. The following will present the results of the UI design implementation that has been made, shown in Fig. 7 for the BEG section of the material and in Fig. 8 for the BEG quiz section.
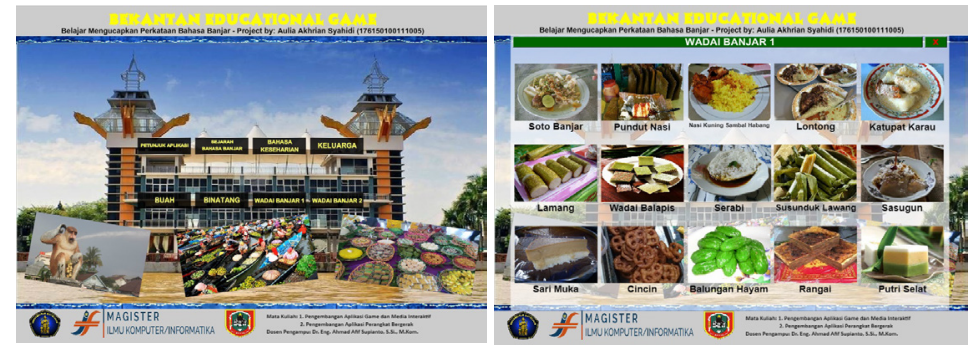

Fig. 7. Implementation of BEG from the material section
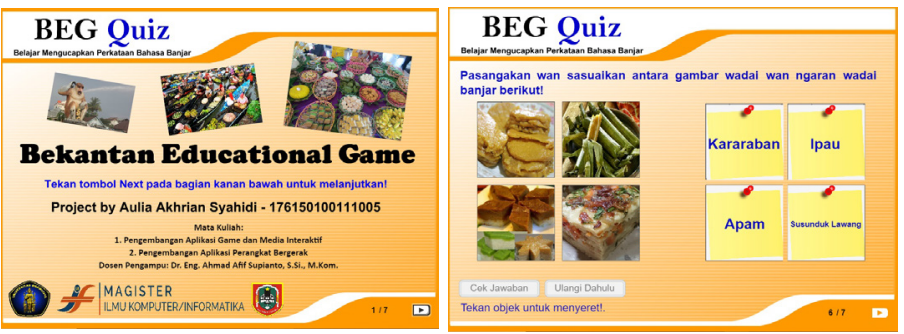

Fig. 8. Implementation of BEG from the quiz section

\section{$5.4 \quad$ Testing}

Test method used in this research is black box testing. Black box testing focuses on the functional requirements of the software. Thus black box testing allows software 
engineers to get a set of input conditions that fully utilize all functional requirements for all programs. The software truths tested are only viewed based on the outputs generated from the data or input conditions provided for the existing functionality regardless of the process to obtain the output. From the output of the program's ability to meet the needs of users can be measured at once can be known errors. Trial with black box on this system aims to determine the function of how to operate, whether the input data output has been running as expected [17]. This test step uses two test cases that is when the system runs in accordance with expectations and when input error occurs. The black box testing results of BEG from Material Section are shown in Table 3 and the black box testing results on BEG from Quiz Section are shown in Table 4.

Table 3. Black box testing results on BEG of material section

\begin{tabular}{|l|l|c|}
\hline \multicolumn{1}{|c|}{ Menu Features } & \multicolumn{1}{|c|}{ Expected Results } & Test Result \\
\hline M1 & $\begin{array}{l}\text { Displays a page that contains the rules or guidelines for using BEG } \\
\text { applications. }\end{array}$ & OK \\
\hline Exit Button on M1 & Return to Main Menu (MU) & OK \\
\hline M2 & Displays a page containing a brief history of Banjar language. & OK \\
\hline Exit Button on M2 & Return to Main Menu (MU) & OK \\
\hline M3 & $\begin{array}{l}\text { Displays a page containing everyday language material that is often } \\
\text { used daily by Banjar people. }\end{array}$ & OK \\
\hline Exit Button on M3 & Return to Main Menu (MU) & OK \\
\hline M4 & Displays a page containing family introduction materials in Banjar. & OK \\
\hline Exit Button on M4 & Return to Main Menu (MU) & OK \\
\hline M5 & Displays a page containing images and fruit names in Banjar. & OK \\
\hline Exit Button on M5 & Return to Main Menu (MU) & OK \\
\hline M6 & Displays a page containing images and animal names in Banjar. & OK \\
\hline Exit Button on M6 & Return to Main Menu (MU) & OK \\
\hline M7 & $\begin{array}{l}\text { Displays a page containing pictures and writings of Banjar's unique food } \\
\text { names in Banjar. }\end{array}$ & OK \\
\hline Exit Button on M7 & Return to Main Menu (MU) & OK \\
\hline M8 & $\begin{array}{l}\text { Displays a page containing pictures and writings of Banjar food names } \\
\text { in Banjar (continued). }\end{array}$ & OK \\
\hline Exit Button on M8 & Return to Main Menu (MU) & OK \\
\hline
\end{tabular}

The results of functionality testing on the BEG part of the material as shown in Table 3 shows that when a player successfully opens this game app that appears is the main page. Then press the Petunjuk Aplikasi (M1) menu, the system reaction displayed successfully with OK status showing the application's guide page that serves to provide information about how to use the game. Next pressing the exit button on M1, the system reaction shown succeeds with the OK status ie back to main page (MU) and close the page M1. Pressing the Sejarah Singkat Bahasa Banjar (M2) menu, the system reaction displayed successfully with the status of OK that displays a short history page of banjar language that serves to display a brief story of the history of the formation of banjar language. Next pressing the exit button on M2, the system reaction shown successfully with OK status is back to the main page (MU) and close the page M2. Pressing the Bahasa Keseharian (M3) menu, the system reaction displayed 
successfully with the status of OK that displays a daily language page that serves to display a variety of Banjar languages are often used in everyday activities. Next pressing the exit button on M3, the system reaction shown succeeds with the OK status ie back to the main page (MU) and close the page M3. Pressing the Keluarga (M4) menu, the system reaction displayed succeeds with an OK status displaying a family page containing the names of family names in Banjar. Next pressing the exit button on M4, the system reaction shown succeeded with OK status ie back to the main page (MU) and close the M4 page. Pressing the Fruit menu (M5), the system reaction displayed succeeds with an OK status displaying a fruit page containing the image and names of fruit summings in Banjar. Next pressing the exit button on the M5, the system reaction shown succeeded with the OK status that is back to the main page (MU) and close the page M5. Pressing the Binatang (M6) menu, the system reaction displayed succeeds with an OK status displaying an animal page containing the image and names of the animal summoning in Banjar. Next pressing the exit button on the M6, the system reaction shown succeeded with the OK status is back to the main page (MU) and close the page M6. Pressing Wadai Banjar 1 (M7) menu, the system reaction displayed successfully with OK status showing Banjar 1 pawn page containing the pictures and names of Banjar pawn callers in Banjar. Next pressing the exit button on M7, the system reaction shown succeeds with the OK status ie back to the main page (MU) and close the page M7. Pressing Wadai Banjar 2 (M8) menu, the system reaction displayed successfully with OK status showing Banjar 2 pandemic page containing the picture and the names of Banjar pawn callers in Banjar language, this menu is a continuation of page M7. Next pressing the exit button on the M8, the system reaction shown succeeded with the OK status is back to the main page (MU) and close the page M8. Based on this it can be said that the results of functionality testing on the BEG of the material part as a whole is in accordance with what is expected.

The result of function testing on the BEG part of the quiz as shown in Table 4 shows that when a player successfully opens this game app that appears is the main page. Then press the next button, the system reaction is successfully displaying the first quiz page of Drag and Drop (K1) quiz type, then the player plays the quiz by pairing or matching between 4 pieces of Wadai Banjar with 4 names of Wadai Banjar by dragging to the right then drop it with OK status. Next press the reset button on $\mathrm{K} 1$, the system reaction shown is to successfully reset the quiz if the player wants to rearrange the quiz because it is caused by mistake put the object, any doubt about the answer given, or any other cause, with OK status. Still on page K1 if the player has been convinced by the answer, press the answer check button with the system reaction is lock the answer and bring up the information whether the answer of the player is right or wrong, with OK status. Lastly after working on the question and the information appears from the answer, the player is welcome to press the next button to proceed to the next quiz page and the player is not allowed back to the main menu.

After pressing the next button on the $\mathrm{K} 1$ page, the system reaction is successfully displaying the second quiz page of Hot Objects (K2) quiz type, then the player plays the quiz by guessing the picture of the fruit based on the question, available 6 pieces of fruit to choose, by clicking on the image of the fruit that is considered correct according to the instruction of the question with the status of $\mathrm{OK}$. Next press the reset 
Table 4. Black box testing results on BEG of quiz section

\begin{tabular}{|c|c|c|}
\hline Quiz Features & Expected Results & Test Result \\
\hline Next Button on MUK & Starts the quiz by displaying the first quiz page. & $\mathrm{OK}$ \\
\hline K1 & $\begin{array}{l}\text { Displays the Drag and Drop quiz type by pairing or matching } \\
\text { images, this quiz system is a picture presented as } 4 \text { pieces on the } \\
\text { left side and on the right side is where to put } 4 \text { pictures in accord- } \\
\text { ance with the naming. }\end{array}$ & OK \\
\hline Reset Button on K1 & Resetting the answer from the quiz $\mathrm{K} 1$. & $\mathrm{OK}$ \\
\hline Check Answer on K1 & $\begin{array}{l}\text { Check out the answers from the quiz } \mathrm{K} 1 \text {. Then bring up the state- } \\
\text { ment whether the quiz that you answer is right or wrong?. }\end{array}$ & OK \\
\hline Next Button on K1 & Continue and display the next quiz. & $\mathrm{OK}$ \\
\hline K2 & $\begin{array}{l}\text { Displays the Hot Objects quiz type in the form of an image that is } \\
\text { guessed by the question asked. This quiz system is a picture } \\
\text { presented as many as } 6 \text { pieces, the player will select the image that } \\
\text { has been provided and adjust it. }\end{array}$ & OK \\
\hline Reset Button on $\mathrm{K} 2$ & Resetting the answer from the quiz K2. & OK \\
\hline Check Answer on K2 & $\begin{array}{l}\text { Check out the answers from the quiz } \mathrm{K} 2 \text {. Then bring up the state- } \\
\text { ment whether the quiz that you answer is right or wrong?. }\end{array}$ & OK \\
\hline Next Button on K2 & Continue and display the next quiz. & OK \\
\hline K3 & $\begin{array}{l}\text { Displaying the Fill in the Blank quiz type, the player will fill in the } \\
\text { answer on the text box provided, and the system does not set case } \\
\text { sensitive. }\end{array}$ & OK \\
\hline Check Answer on K3 & $\begin{array}{l}\text { Check out the answers from the quiz K3. Then bring up the state- } \\
\text { ment whether the quiz that you answer is right or wrong?. }\end{array}$ & OK \\
\hline Next Button on K3 & Continue and display the next quiz. & OK \\
\hline K4 & $\begin{array}{l}\text { Displays the Hot Spot quiz type of the image guessed by the } \\
\text { question asked. This quiz system is a picture presented as many as } \\
6 \text { pieces, the player will select the image that has been provided } \\
\text { and adjust it. }\end{array}$ & OK \\
\hline Reset Button on K4 & Resetting the answer from the quiz K4. & OK \\
\hline Check Answer on K4 & $\begin{array}{l}\text { Check out the answers from the quiz K4. Then bring up the state- } \\
\text { ment whether the quiz that you answer is right or wrong?. }\end{array}$ & OK \\
\hline Next Button on K4 & Continue and display the next quiz. & OK \\
\hline K5 & $\begin{array}{l}\text { Displaying the True or False quiz type is choosing whether the } \\
\text { answer is right or wrong and only one correct answer, the player } \\
\text { will choose between the right or wrong options that have been } \\
\text { provided according to the instructions of the statement by clicking } \\
\text { on the option on the answer. }\end{array}$ & OK \\
\hline Check Answer on K5 & $\begin{array}{l}\text { Check out the answers from the quiz K5. Then bring up the state- } \\
\text { ment whether the quiz that you answer is right or wrong?. }\end{array}$ & $\mathrm{OK}$ \\
\hline Next Button on K5 & Continue and display the next quiz. & OK \\
\hline K6 & $\begin{array}{l}\text { Displaying a multiple choice quiz type, the player will select some } \\
\text { correct answers that have been provided in accordance with the } \\
\text { question instruction by clicking on the options in the answer. }\end{array}$ & OK \\
\hline Check Answer on K6 & $\begin{array}{l}\text { Check out the answers from the quiz K6. Then bring up the state- } \\
\text { ment whether the quiz that you answer is right or wrong?. }\end{array}$ & $\mathrm{OK}$ \\
\hline Next Button on K6 & Continue and show results from the quiz. & OK \\
\hline QR & $\begin{array}{l}\text { Displays the end result of the quiz work, consisting of true totals, } \\
\text { total wrongs, and total score. }\end{array}$ & $\mathrm{OK}$ \\
\hline
\end{tabular}

button on $\mathrm{K} 2$, the system reaction shown is to successfully rearrange the quiz if the player wants to rearrange the quiz because it is caused by mistake pressing the object, any doubt about the answer given, or any other cause, with OK status. Still on page 
K2 if the player has been convinced by the answer, press the check button the answer with the system reaction is lock the answer and bring up the information whether the answer of the player is right or wrong, with status OK. Finally after working on the question and the information from the answer appears, the player is invited to press the next button to proceed to the next quiz page and the player is not allowed to return to the previous quiz page.

Then after pressing the next button on the K2 page, the system reaction is successfully displaying the third quiz page of Fill in the Blank (K3) quiz type, and then the player plays the quiz by filling the answer in the text box directly input or typed in quiz question or quiz with status OK. In this type of quiz K3 is not disedikan reset button because the player such as doubt can directly delete the answer before clicking the check button answer. If the player has been convinced by the answer, press the check button with the reaction of the system is lock the answer and bring up the information whether the answer from the player is right or wrong, with the status OK. Finally after working on the question and the information from the answer appears, the player is invited to press the next button to proceed to the next quiz page and the player is not allowed to return to the previous quiz page.

After pressing the next button on the K3 page, the system reaction is successfully displaying the fourth quiz i.e. Hot Spot quiz (K4), then the player plays the quiz by guessing the animal image based on the question, available 6 pieces of animal image to choose, by clicking the picture animals considered true according to the instruction of the question with OK status. Next press the reset button on K4, the system reaction shown is to successfully rearrange the quiz if the player wants to reset the quiz because it is caused by mistake pressing the object, any doubt about the answer given, or any other cause, with OK status. Still on the K4 page if the player has been convinced by the answer, hit the check button with the system reaction is to lock the answer and bring up the information whether the answer of the player is right or wrong, with OK status. Finally after working on the question and the information from the answer appears, the player is invited to press the next button to proceed to the next quiz page and the player is not allowed to return to the previous quiz page.

Then after pressing the next button on the K4 page, the system reaction is successfully displaying the fifth quiz page ie True or False (K5) quiz type, and then the player plays quiz by selecting one answer between true or false based on query question or statement with OK status. In this type of quiz $\mathrm{K} 5$ is not disedikan reset button because the player can directly switch options on the radio button before clicking the check button answer. If the player has been convinced by the answer, press the check button with the reaction of the system is lock the answer and bring up the information whether the answer from the player is right or wrong, with the status OK. Finally, after working on the question and the information from the answer appears, the player is invited to press the next button to proceed to the next quiz page and the player is not allowed to return to the previous quiz page.

After pressing the next button on the K5 page, the system reaction is successfully displaying the sixth quiz page which is the quiz type Multiple Choice (K6) is the last quiz, the player plays this quiz by selecting some answers from 5 options provided based on questions or statements from the quiz, the correct answer will amount to 
more than 1 of the players have to answer it, this quiz has succeeded with status OK. In the K6 quiz type is not disedikan reset button because the player can directly switch the option on the radio button before clicking the check button answer. If the player has been convinced by the answer, press the check button with the reaction of the system is lock the answer and bring up the information whether the answer from the player is right or wrong, with the status OK. Lastly, after working on the question and the information appears from the answer, the player is invited to press the next button to proceed to the final results page of the quiz and the player is not allowed to return to the previous quiz page.

Lastly after pressing the next button on page K6, the system's reaction is to successfully display the Quiz Result page $(\mathrm{QR})$ which is a quiz result consisting of total true, total wrong, and total score. Once the player knows the final result on this $\mathrm{QR}$ page, the live gamer closes the game app and the final quiz is done successfully and finishes with OK status. Based on this it can be said that the results of functionality testing on the BEG quiz section as a whole is in accordance with the expected.

This stage is done after the application is finished designed. Testing is done by selecting the sample to use the application directly from the player. There are twelve people from university students in Malang City where they are native people of South Kalimantan who tend to be able to speak Banjar. Implementation of testing to one of the players is shown in Fig. 9.
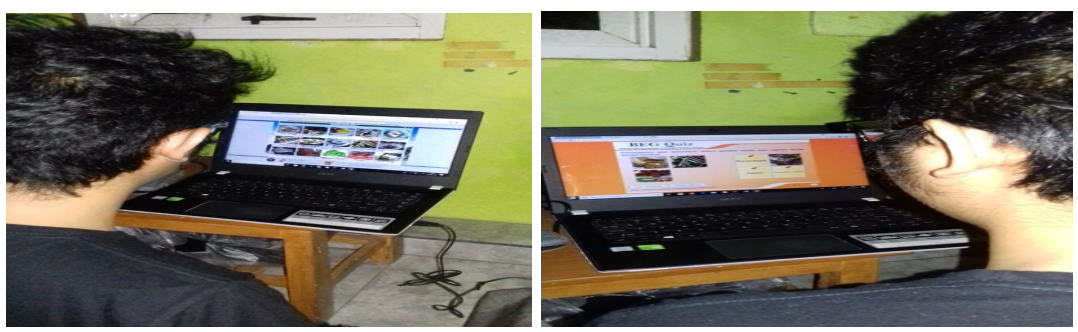

Fig. 9. Implementation of testing to one of the players

Twelve sample persons to use BEG applications with test results are presented in Table 5 and Table 6.

In Table 5 analyzed which menu is frequently accessed by players, the lowest or least accessed total is M1: Petunjuk Aplikasi with a total of 26. The Application Instruction menu is most likely not too often or rarely accessed because players tend to look for the way itself to playing apps and also the average player is an adult, so the App Guide Menu is only considered as a reference or regular instruction that indirectly does not read any player who has understood how to use the app. The menu is often accessed menu M8: Wadai Banjar 2 with a total of 59. Wadai Banjar 2 menu on the results of this analysis is a menu that is often accessed by players, the possibility that players like the form of material visualized in the form of images and text is good and interesting, and specificity in BEG applications This material section is located in Wadai Banjar 1 and 2 menus, as it is characteristic of regionalism. 
Table 5. Result of frequency test accessing menu in BEG material section

\begin{tabular}{|c|c|c|c|c|c|c|c|c|c|}
\hline \multirow{2}{*}{ Players } & \multirow{2}{*}{ Initial Name } & \multicolumn{8}{|c|}{ Menu Features } \\
\hline & & M1 & $M 2$ & M3 & M4 & $M 5$ & M6 & M7 & M8 \\
\hline 1 & ZM & 3 & 4 & 4 & 4 & 4 & 5 & 5 & 6 \\
\hline 2 & YA & 2 & 2 & 3 & 3 & 4 & 4 & 4 & 5 \\
\hline 3 & SM & 3 & 3 & 2 & 3 & 3 & 2 & 5 & 6 \\
\hline 4 & $\mathrm{MN}$ & 1 & 2 & 3 & 3 & 4 & 5 & 4 & 7 \\
\hline 5 & MEiA & 1 & 3 & 3 & 2 & 5 & 2 & 3 & 6 \\
\hline 6 & $\mathrm{MEaA}$ & 2 & 2 & 3 & 4 & 4 & 3 & 3 & 5 \\
\hline 7 & MHA & 3 & 3 & 2 & 3 & 5 & 4 & 4 & 4 \\
\hline 8 & MG & 2 & 2 & 4 & 2 & 4 & 3 & 3 & 5 \\
\hline 9 & RAS & 3 & 3 & 3 & 4 & 4 & 3 & 5 & 4 \\
\hline 10 & $\mathrm{JI}$ & 3 & 2 & 2 & 2 & 2 & 4 & 3 & 3 \\
\hline 11 & LM & 2 & 3 & 4 & 3 & 3 & 3 & 5 & 4 \\
\hline 12 & EPD & 1 & 2 & 3 & 2 & 4 & 3 & 4 & 4 \\
\hline Total & & 26 & 31 & 36 & 35 & 46 & 41 & 48 & 59 \\
\hline
\end{tabular}

Table 6. Result of frequency test accessing menu in BEG material section

\begin{tabular}{|c|l|c|c|c|c|c|c|c|}
\hline \multirow{2}{*}{ Players } & \multirow{2}{*}{ Initial Name } & \multicolumn{9}{|c|}{ Quiz Features } & \multirow{2}{*}{ Score } \\
\cline { 3 - 8 } & & $\boldsymbol{K} \mathbf{1}$ & $\boldsymbol{K} \mathbf{2}$ & $\boldsymbol{K} 3$ & $\boldsymbol{K} 4$ & $\boldsymbol{K 5}$ & $\boldsymbol{K} \boldsymbol{6}$ & \\
\hline 1 & ZM & 3 & 3 & 2 & 2 & 1 & 0 & $100 \%$ \\
\hline 2 & YA & 1 & 0 & 2 & 3 & 0 & 1 & $90 \%$ \\
\hline 3 & SM & 3 & 2 & 1 & 1 & 0 & 0 & $80 \%$ \\
\hline 4 & MN & 1 & 0 & 0 & 0 & 1 & 1 & $80 \%$ \\
\hline 5 & MEiA & 2 & 0 & 0 & 0 & 0 & 2 & $80 \%$ \\
\hline 6 & MEaA & 1 & 2 & 3 & 1 & 1 & 1 & $100 \%$ \\
\hline 7 & MHA & 2 & 2 & 3 & 1 & 1 & 0 & $100 \%$ \\
\hline 8 & MG & 1 & 1 & 1 & 2 & 1 & 1 & $100 \%$ \\
\hline 9 & RAS & 1 & 0 & 1 & 2 & 1 & 1 & $90 \%$ \\
\hline 10 & JI & 2 & 0 & 0 & 0 & 0 & 1 & $100 \%$ \\
\hline 11 & LM & 2 & 1 & 2 & 0 & 0 & 2 & $70 \%$ \\
\hline 12 & EPD & 21 & 12 & 16 & 13 & 6 & 11 & $89.17 \%$ \\
\hline Total
\end{tabular}

In Table 6 analyzed is how often players rearrange answers when answering a quiz based on quiz types. Based on Table 6 , the quiz that is often rearranged by players is K1: Drag and Drop quiz with a total of 21 reset. Drag and Drop here may be a rather difficult quiz type because of the way layout between the image object and the name object that should match it, the player in this case tends to hesitate to put the image to the name object and is released to another name object, resulting in the player must reset the answer. Quizzes that rarely rearrange the answers by players are K5 quiz types: True or False with 6 reset totals. This type of quiz True or False is quite easy because there are only two choices of objective answers, and questions or statements presented there are some players tend to have been known. Then reviewed from the final result after the quiz works, the player provides excellent feedback as evidenced by the average score obtained is $1070 / 12=89.17 \%$. 


\section{Conclusion}

Through this research has been successfully done the design and implementation of educational game applications called Bekantan Educational Game (BEG) which can be recommended for use as a medium of learning Banjar language. It has been tested for twelve players. Based on testing with black box testing that all the functionality in the BEG application matches what is expected. Based on the results of the analysis of players, players are more interested in material that has visualization of images and text than text only because the proof is on the analysis of how often the menu is accessed in M8: Wadai Banjar 2 menu with a total of 59 times access. The result of player behavior analysis on frequency reset the answer on the quiz, got K1: Drag and Drop quiz with 21 times reset. With the quiz, the player has provided excellent feedback with an average end score of $89.17 \%$.

\section{$7 \quad$ Limitations and Future Work}

Current research focuses on the design and implementation of Bekantan Educational Game (BEG), its implementation is still on BEG using desktop and web based, then testing is done by black box testing method, frequency of accessing menu test in BEG part of material, and frequency of reset quiz in BEG quiz section. In the future, BEG applications are also expected to be implemented on a mobile base, test white box testing, usability testing, and evaluate the implementation of BEG to the general public.

\section{Acknowledgement}

The first author would like to thank the leaders and all lecturers of Master of Computer Science, Faculty of Computer Science, Brawijaya University of Malang, Indonesia, to facilitate to research and publish this paper. Paper submitted as a substitute to fulfill the request of RISET FILKOM UB scholarship for the academic year 2017/2018 of the silver category in Master of Computer Science, Faculty of Computer Science, Brawijaya University of Malang, Indonesia.

\section{$9 \quad$ References}

[1] Rahman, Taufik. (2006). Tanah Banjar: Intelektualisme Tak Pernah Mati. Banjarmasin: Penakita

[2] Alam, Sutan Takdir. (2014). Aplikasi Permainan dan Pembelajaran Seni dan Budaya Banjar "Petualangan Si Palui". Universitas Lambung Mangkurat. Banjarbaru

[3] Kurniawan, Yahya. (2005). Kiat Praktis Menguasai Actionscript 2.0 Flash MX. Yogyakarta: PT. Elex Media Computindo 
[4] Takdir Alam, Sutan., et. al. (2014). Rancang Bangun Aplikasi Permainan (Games) sebagai Media Pembelajaran Seni dan Budaya Banjar. Kumpulan Jurnal Ilmu Komputer (KLIK). Volume 01, No.01 September 2014. ISSN: 2406-7857

[5] Hartono, M., et. al. (2017). Educational mathematics game for elementary students. 2017 International Conference on Information Management and Technology (ICIMTech), Yogyakarta, pp. 156-159. https://doi.org/10.1109/ICIMTech.2017.8273529

[6] Grill, Thomas. (2012). Mobile Games Development and Design - Human Computer Interaction and Usability Unit. University of Salzburg. Mittwoch

[7] Hermawan, D. P., \& Herumurti, D. (n.d.). (2017). Efektivitas Penggunaan Game Edukasi Berjenis Puzzle, RPG dan Puzzle RPG sebagai Sarana Belajar Matematika. JUTI: Jurnal Ilmiah Teknologi Informasi - Volume 15, Nomor 2, Juli 2017: 195 - 205 https://doi.org/10.12962/j24068535.v15i2.a663

[8] Ismail, Andang. (2006). Education Games. Yogyakarta: Pilar Media

[9] https://id.wikipedia.org/wiki/Bahasa Banjar [Accessed: 01-June-2018]

[10] Sulistio, M. B., Et. al. (201ET. Game Edukasi Berbasis KINECT untuk Siswa Tunagrahita Ringan Tingkat SMA (GEMASKIT), 1(1), 702-709

[11] Rohwati, M. (2012). Penggunaan Education Game untuk Meningkatkan Hasil Belajar IPA Biologi Konsep Klasifikasi Makhluk Hidup. JPII 1 (1) (2012) 75-81

[12] Vitianingsih, A. V. (2016). Game Edukasi Sebagai Media Pembelajaran Pendidikan Anak Usia Dini, 1(1), 1-8

[13] Songgo Panggayudi, Dwi. (2017). Media Game Edukasi Berbasis Budaya untuk Pembelajaran Pengenalan Bilangan pada Anak Usia Dini. MUST: Journal of Mathematics Education, Science and Technology Vol. 2, No. 2, Desember 2017. Hal. 91-102 https://doi.org/10.30651/must.v2i2.883

[14] Moumoutzis, N., et al. (2017). Using new media arts to enable project-based learning in technological education. 2017 IEEE Global Engineering Education Conference (EDUCON), Athens, pp. 287-296. https://doi.org/10.1109/EDUCON.2017.7942861

[15] Delima, R., Arianti, N. K., \& Pramudyawardani, B. (2015). Identifikasi Kebutuhan Pengguna Untuk Aplikasi Permainan Edukasi Bagi Anak Usia 4 sampai 6 Tahun, 1(April)

[16] Marendra., et. al. (2016). Perancangan Game Edukasi Berbasis Matematika untuk Meningkatkan Minat Belajar Anak Sekolah Dasar

[17] Nidhra, S. (2012). Black Box and White Box Testing Techniques - A Literature Review. International Journal of Embedded Systems and Applications, 2(2), 29-50. https://doi.org/10.5121/ijesa.2012.2204

\section{Authors}

Aulia Akhrian Syahidi is one of the students from the Master of Computer Science at the Faculty of Computer Science, Brawijaya University of Malang, Indonesia. He was awarded a scholarship RISET FILKOM UB academic year 2017/2018 with silver category. He is a graduate of Information Technology Education (S.Pd.) from STKIP PGRI Banjarmasin. Now has a vocational high school teacher and a busy research assistant in the Media, Game, and Mobile Technologies research group. In April 2018 he first managed to publish his research results in a scopus-indexed paper at the IOP Conference Series: Material Science and Engineering from the results of the 2017 ICVEE conference. (E-mail: aakhriansyahidi@student.ub.ac.id) 
Mr. Ahmad Afif Supianto is a lecturer in Master of Computer Science at the Faculty of Computer Science, Brawijaya University of Malang, Indonesia. Graduate of Doctor of Engineering (Dr. Eng.) from Department of Information Engineering, Graduate School of Engineering, Hiroshima University, Japan. Completed a Bachelor of Science (S.Si) Department of Computational Mathematics at the Faculty of Mathematics and Natural Sciences at the Institute of Sepuluh Nopember Surabaya then continued his Master of Computer Science (M.Kom.) Department of Informatics at the Faculty of Information Technology at the Institute of Sepuluh Nopember Surabaya. Has published many research results in the form of internationally reputed scopus indexed paper. His fields are Machine Learning, Pattern Recognition, Data Mining and Knowledge Discovery, Learning Analytics, and Educational Game. (E-mail: afif.supianto@ub.ac.id)

Mr. Herman Tolle is one of the senior lecturers in the Master of Computer Science at the Faculty of Computer Science, Brawijaya University of Malang, Indonesia. Graduate of Doctor of Engineering (Dr. Eng.) from Department of Information Science, Graduate School of Science and Engineering, Saga University, Japan. Has published many research results in the form of internationally reputed scopus indexed paper. Has completed Bachelor of Engineering (S.T.) in Department of Electrical Engineering in Brawijaya University then continued study of Master of Telecommunication Information System (M.T.) at Bandung Institute of Technology. Current position is the Head of Information System Department FILKOM UB, and Coordinator of Research Group of Media, Game, and Mobile Technologies. His fields are Mobile Application Development, Human Computer Interaction, Web Development, Multimedia, Information Retrieval, Image Processing, Artificial Intelligence, and ELearning. (E-mail: emang@ub.ac.id)

Article submitted 2018-07-21. Resubmitted 2018-10-13. Final acceptance 2018-10-21. Final version published as submitted by the authors. 